\title{
New Characteristics of College Students' Ideological Dynamics and Innovation of Ideological and Political Education Methods based on Psychological Education
}

\author{
Haixin Jiang* \\ School of Marxism, Jiamusi University, Jiamusi 154000, Heilongjiang Province, China \\ *Corresponding author: Haixin Jiang, 2392940446@qq.com
}

\begin{abstract}
Under the influence of social environment, the ideological dynamics of college students have tremendously changed. Among them, the biggest change is that the psychological reception mechanism is very different from the level of self-cognition. Since the report of the $17^{\text {th }}$ National Congress of the Communist Party of China, the state has formed an agenda to strengthen the ideological and political education in colleges and universities, among which, it is important to reinforce humanistic care and psychological counseling. Mental health education is inextricably linked to the ideological and political education in colleges and universities. Therefore, this article begins in the perspective of psychological education, analyzes the ideological dynamic characteristics of college students, summarizes effective principles and important measures of ideological and political education innovation methods in order to maximize the constructive role of ideological and political education.
\end{abstract}

Keywords: Psychological education; New features; College ideological and political education; Methods innovation

Publication date: June 2021; Online publication: June 30, 2021

\section{New characteristics of college students' ideological dynamics}

\subsection{Attaching importance to self-feeling and the pursue of individual characteristics}

College students have a comfortable living environment at home in which they are taken care of and loved by their parents and elders. As a result, they focus more on their own feelings in regard to their mental cognition and they seldom think from the perspective of others.

The first consideration of these college students in their choice of things is whether it meets their expectations or aesthetic standards, and whether it is what they want subjectively. They do not give much thought to the objective external conditions but decide the nature of things according to their own preferences. Strong self-awareness forms college students' attitudes toward things; those that they are interested in and those that they are not. They would usually ignore things which they are not interested in.

\subsection{Higher psychological sensitivity and weak in resisting setbacks}

Majority of modern-day college students are the only child in their family and generally, their growth environment is optimal in which their parents or elders meticulously provide adequate care and concern. Such growth experience is too simple; hence, college students would gradually display higher psychological sensitivity in the face of new environments especially after they step into college. For a long time, the traditional mode of education shapes students to have strong learning skills and competitive consciousness, 
however, compared to this batch of college students, their moods are particularly susceptible to the influence of the surrounding environment, prone to be swayed by considerations of gain and loss of psychological characteristics, and once they encounter difficulties or setbacks, they will have a negative attitude. These group of college students are extremely sensitive which lead them to accumulate thoughts in their minds instead of communicating with others. They are extremely restrained, and they prefer to hide their true feelings as well as expressions of happiness or sadness. Such a sensitive psychological state of fearing to be exposed increases the difficulty in the ideological and political education.

\section{Relationship between mental health education and the ideological and political education in colleges and universities}

\subsection{Differences between mental health education and the ideological and political education in colleges and universities}

Mental health education in colleges and universities started in the 1980s and the main purpose of this course is to understand and grasp the psychological characteristics of college students and implement psychological education methods in means to optimize and improve college students' psychological structure, encourage students' excellent psychological qualities, and eventually, promote a well-rounded development. The focus of mental health education is the correction and maintenance of existing psychological problems while the focus of ideological and political education is to train students' ideological and moral cultivation in the effort to train up a generation with a certain political color for the development of China's social economy. These educations belong to different disciplines hence, the theoretical basis also differs but the most critical difference is in the specific objectives.

\subsection{Relations between mental health education and ideological and political education in colleges and universities}

2.2.1. Mental health education and ideological and political education in colleges and universities are consistent at the core

On the one hand, the main subject of mental health education and ideological and political education in colleges and universities is the college students. In addition to that, both of them are inclined to ideological and spiritual education. The ideological and political level of college students and their mental health level complement each other but they also influence one another. The ideological and cognitive level affects students' psychological bearing abilities while students' psychological state directly affects their value orientations. The natural combination of the two can promote a well-rounded development in students. On the other hand, from the perspective of the education faculty, the mental health education workers in college are important as part of the working group of the ideological and political education. Ideological and political education workers in colleges and universities once found that the effect from their own education is not effective, hence the introduction of the mental health education which provides another angle to improve students' ideological and political qualities. It is the ideological and political education workers that have become guides for the mental health education in colleges and universities. With the continuous development of mental health education, colleges and universities regard both the mental health education and the ideological and political education as important aspects of college students' ideological education.

\subsubsection{Mental health education promotes value orientation}

People's behaviors are influenced by their own values which is why colleges and universities have high regards for ideological and political education. The internal harmony between thought and psychology will directly affect students' mental state, emotional changes, and other ideological activities, thus influencing 
students' specific behavior. Therefore, it is easy to recognize that the mental health education in colleges and universities would not only help college students to channel their emotions, relieve pressures, and build healthy psychological structures but it would also have a certain positive significance to the value orientation of students. This kind of value orientation is different from the indoctrination and explanation of ideological and political education but implies more on the subjective acceptance of one's own inner world. Mental health education mainly helps students to feel with their hearts, explore their emotions, and then actively guide them to form correct cognitions in the perceptual process so that values can be truly communicated in this manner.

\subsubsection{Choice of ideological and political education methods based on the theoretical basis and practical experiences of mental health education}

The teaching of mental health education is based on the psychology theory which focuses on students' true feelings and perceptual knowledge.

By learning the theoretical basis of mental health education and making effective use of it, it can effectively provide support for the choice of ideological and political education methods in colleges and universities. Although there is a huge fundamental difference between mental health education and the ideological and political education, ideological and political education in the form of conversations has a strong purpose. Through conversations, ideological and political thoughts are communicated, and students are guided to form correct values. From the analysis of methods and skills, it is found that the relaxed environment that is created during mental health education brought about a certain affinity among students so that they may learn more easily. This, to a certain extent, provides a new method for the ideological and political education.

\section{Innovative measures for the ideological and political education in colleges and universities based on psychological education}

\subsection{Raising the professional level of the team and promoting the scientific construction of ideological and political education}

Mental health education tends to focus more on perceptual knowledge while ideological and political education is contrary to that in which it tends to emphasize on rational knowledge and is based on political science, sociology, etc. as its main subjects. With the progress of the society, the teaching modes in education are also changing. Contemporary college students' mental states are becoming more and more unstable with their fluctuating moods. Hence, this is a big challenge for universities' ideological and political education workers. The ideological and political educators in colleges and universities need to have solid professional theoretical foundations while keeping in mind the psychology and education theories. This is to reinforce the adjustments of students' ideological changes in their adaptation and understanding toward environmental factors through the teaching of theories. Only with these basic theories, the ideological and political education workers in colleges and universities may fully understand students' ideological behaviors and their behavioral dynamics in addition to analyzing the actual reasons for these changes. Therefore, ideological and political education workers should constantly improve their professional quality, study hard, work together with multiple disciplines, actively involve themselves in multidisciplinary trainings, as well as improve their levels of specialization in order to strengthen the construction of the ideological and political education working group. 


\subsection{Emphasizing on two-way communication and interaction as well as expanding new methods of ideological and political education}

In regard to the main role of ideological and political education theory, there is a need to explore new teaching methods in line with the latest education situation.

New ideological and political education methods should be continuously explored. The traditional ideological and political education method is that the educator plays the dominant role in classrooms in guiding and cultivating students' thoughts and values. However, with the continuous innovation of ideological and political education methods, this dominant role should be expressed in a new way to enhance the influence of education. It is not difficult to transform the ideological and political education method of the dominant role of one party into a two-way communication and interaction in combination with the characteristic of the enhanced self-awareness among college students in this new era. In this way, the democratic principle can be fully reflected, not only through the educators, but also through the expression of students by their participation in ideological and political education. Of course, equal communication and discussion on relevant contents have demanded higher requirements in terms of the professional level of the educators. Educators need to convey and integrate the key contents of ideological and political education in the process of communication, hence imperceptibly improve students' ideological and political literacy.

\subsection{Improving the affinity of ideological and political education methods and replacing preaching with psychological counseling}

Differing from the Western, the psychological counseling in China's ideological and political education is not simply a mental health guidance in literal sense but it focuses on improving the affinity of ideological and political education methods, as well as the development and innovation of didactic education. Although preaching is associated with indoctrination, they are fundamentally different. As the saying goes, "convince people by reason." Therefore, reasoning education has played an irreplaceable role with this affinity. With the continuous development of the society, people's minds are becoming more and more open, leading to a diversified understanding of human thoughts. The reasoning education method needs to be innovated as the invariable preaching can no longer meet the needs of social development. In this period, the importance of psychological counseling can be appreciated. Using psychological counseling instead of reasoning education, there is more affinity and rich emotions are expressed. From the angle of psychology, there are diversity of thoughts in education, hence there is a need to increase the affinity of the ideological and political education teaching methods with psychological counseling; on one hand, in terms of ideological and political contents and on the other hand, strengthening students' emotions, conducting education work in a gentle manner, and giving full play to the true meaning of ideological and political education.

\section{Conclusion}

The main purpose of ideological and political education in colleges and universities is to cultivate students into well-rounded talents. This raises the standards of the ideological and political education goals in colleges and universities. With the continuous development of social changes, the ideological and political education is facing many challenges, hence, the traditional ideological and political education cannot completely solve the psychological pressure faced by college students. In regard to that, in the perspective of psychological education for university students' new ideological dynamic characteristics and the analysis of ideological and political education methods, there is a need for innovation and improvement of the ideological and political education teaching methods to cultivate high-quality successors and builders for the construction of socialism with Chinese characteristics. 


\section{Disclosure statement}

The author declares no conflict of interest.

\section{References}

[1] Chen M, Wang X, 2017, Innovation of ideological and political education methods for college students from the perspective of educational objects. Ideological and Theoretical Education Guide, (08).

[2] Tan S, 2016, Innovative strategies of ideological and political education methods for college students. Education Modernization, (38).

[3] Wei Q, 2013, "Bottleneck" and innovation of research on ideological and political education methods. Research on Ideological Education, (10).

[4] She S, 2011, From reasoning education to psychological counseling - development of ideological and political education methods. Research on Marxism at Peking University, (00).

[5] Huang W, 2007, On the combination of ideological and political education and psychological education in universities. Higher Education Forum, (04).

[6] $\mathrm{Zu} \mathrm{J,} \mathrm{2007,} \mathrm{Reflections} \mathrm{on} \mathrm{the} \mathrm{subject} \mathrm{and} \mathrm{characteristics} \mathrm{of} \mathrm{ideological} \mathrm{and} \mathrm{political} \mathrm{education.}$ Teaching and Research, (03).

[7] Hai M, 2018, Research and analysis of college students' ideological dynamics and educational countermeasures - taking the school of mechanical engineering, inner Mongolia university of technology as an example. Think Tank Era, (31).

[8] Wang D, Cai L, 2019, A brief analysis of the ideological dynamics of contemporary college students and the coping direction of ideological and political education in colleges and universities. Youth and Society, (21).

[9] Zhang D, 2018, A brief analysis of innovation research of ideological and political education methods for college students. Home of Drama, (16).

[10] Liu Q, 2019, Research on the long-term mechanism of improving the quality of college students' ideological and political education. Education Modernization, (A5). 